\title{
Impacts on cooling energy consumption due to the UHI and vegetation changes in Manchester, UK
}

DOI:

10.1016/j.enbuild.2016.01.035

\section{Document Version}

Accepted author manuscript

Link to publication record in Manchester Research Explorer

\section{Citation for published version (APA):}

Skelhorn, C. P., Levermore, G., \& Lindley, S. J. (2016). Impacts on cooling energy consumption due to the UHI and vegetation changes in Manchester, UK. Energy and Buildings, 122, 150-159.

https://doi.org/10.1016/j.enbuild.2016.01.035

\section{Published in:}

Energy and Buildings

\section{Citing this paper}

Please note that where the full-text provided on Manchester Research Explorer is the Author Accepted Manuscript or Proof version this may differ from the final Published version. If citing, it is advised that you check and use the publisher's definitive version.

\section{General rights}

Copyright and moral rights for the publications made accessible in the Research Explorer are retained by the authors and/or other copyright owners and it is a condition of accessing publications that users recognise and abide by the legal requirements associated with these rights.

\section{Takedown policy}

If you believe that this document breaches copyright please refer to the University of Manchester's Takedown Procedures [http://man.ac.uk/04Y6Bo] or contact uml.scholarlycommunications@manchester.ac.uk providing relevant details, so we can investigate your claim.

\section{OPEN ACCESS}


Impacts on Cooling Energy Consumption Due to the UHI and Vegetation Changes in Manchester, UK

Cynthia P. Skelhorn, University of Manchester, School of Environment, Education and Development (UK) ${ }^{1}$

Geoff Levermore, University of Manchester, School of Mechanical, Aerospace, and Civil Engineering (UK)

Sarah J. Lindley, University of Manchester, School of Environment, Education and Development (UK)

${ }^{1}$ Corresponding Author: cynthia.skelhorn@manchester.ac.uk, +97466969182, PO Box 26999, Doha, Qatar 


\section{Introduction}

Climate change projections estimate a rise of approximately $3{ }^{\circ} \mathrm{C}$ by the 2080 's for most of the UK (under a medium emissions scenario at 50\% probability level, 1961-1990 baseline) [1]. Warming is of particular concern for urban areas due to the issues of urban densification and the Urban Heat Island (UHI) effect. This paper utilises research on the Urban Heat Island Intensity (UHII) (the temperature difference between the city centre and a rural reference location) in Manchester and Greater Manchester [2], a city and urban area in the northwest of England, UK. The research found that the UHII can reach $8{ }^{\circ} \mathrm{C}$ and is also increasing over time. Figure 1 shows the frequency distribution based on half-hourly readings from 11 measured locations in Manchester city centre during May to August 2010 [2,3].

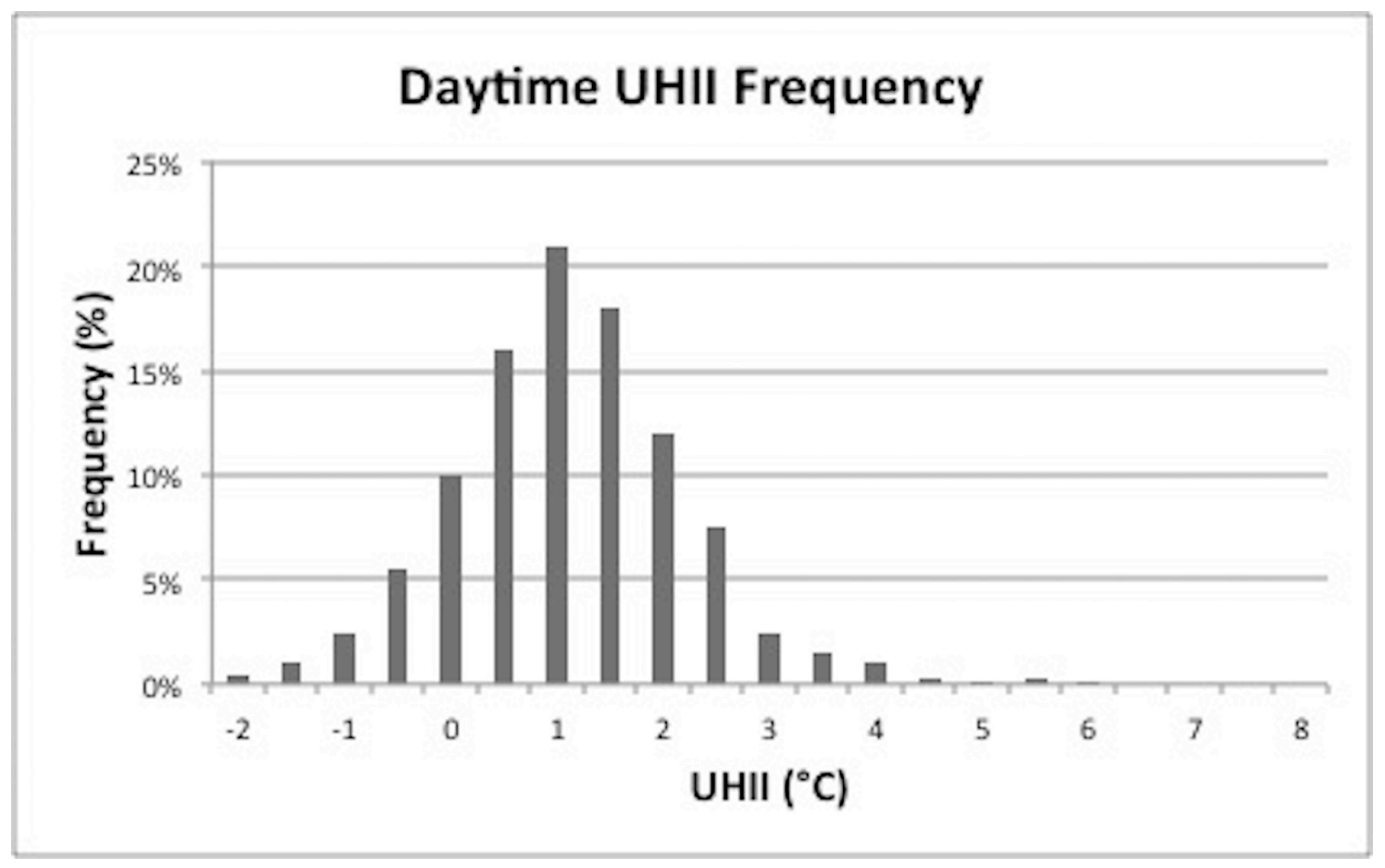




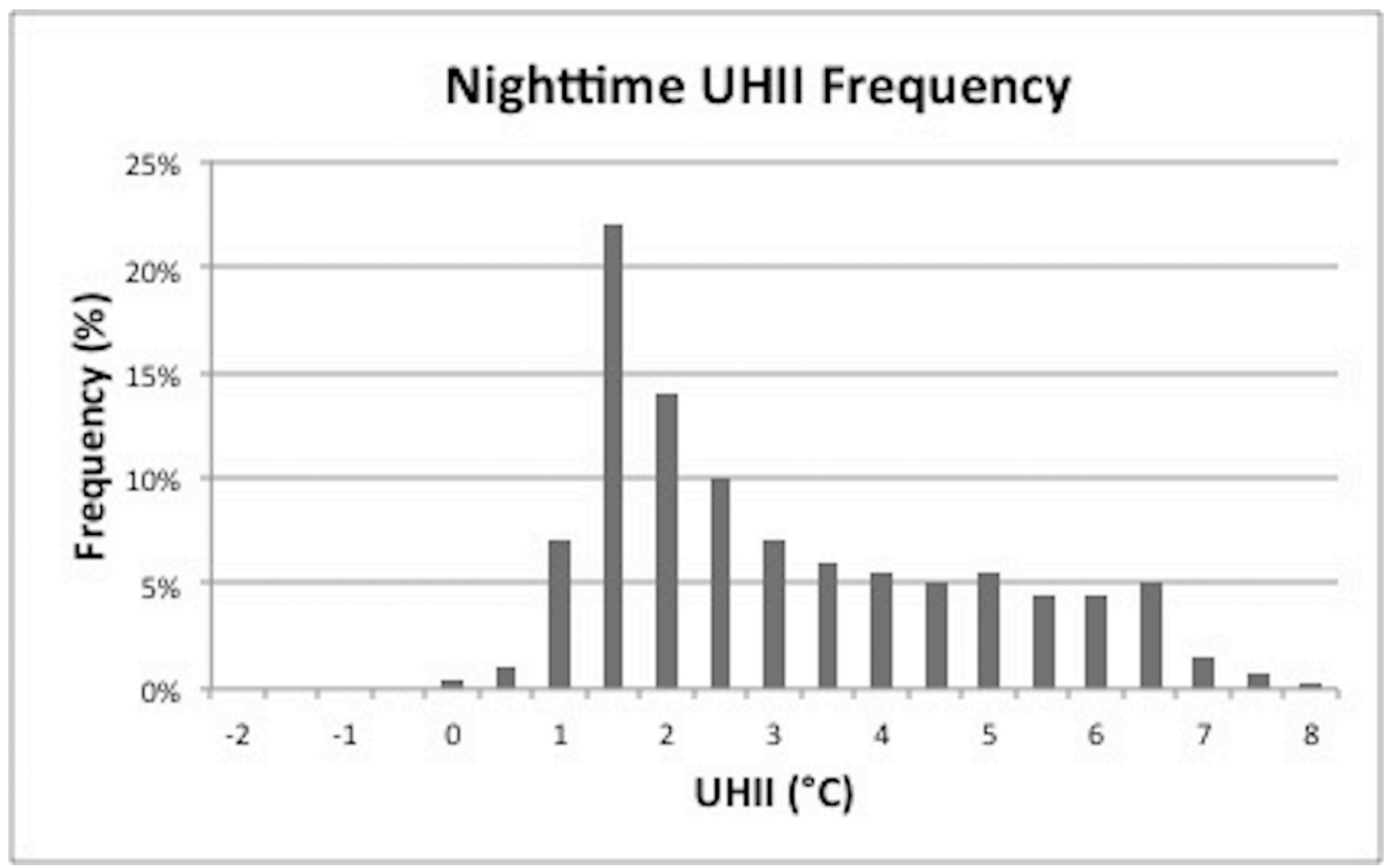

Figure 1 - Histograms of Summer Daytime and Nighttime UHII Frequency for Manchester [2]

As an adaptation to both climate change and the UHI, one strategy that has been suggested for urban areas is increasing the proportion of greenspace [4,5], such as public parks [6,7], gardens, street trees [8-10], and green roofs. While many studies have investigated the cooling effect of greenspace in terms of park size $[11,12]$, proximity to a park, or area covered by tree canopy (see Bowler et al. [5] for a comprehensive review), and other studies have explored the impact of the UHI or microclimate on building energy demand [13-18], relatively few studies have specifically explored the impacts of vegetation in urban environments on building energy demand.

Those that have investigated building energy demand have primarily focused on residential buildings [19-23], most frequently for humid tropical/sub-tropical or Mediterranean climates [24,25] rather than for temperate maritime climates (Koppen climate classification [26]), such as that of the UK. Of those that have included vegetation, most have 
analysed building energy (and/or $\mathrm{CO}_{2}$ emissions) solely as function of one variable, either air temperature or shading effects, with a wide range of variation.

As early as 1977, research by Mattingly and Peters [27] on the sheltering and building energy effects of fences, adjacent houses, and tall evergreen trees found that a straight row of evergreen trees was the most effective scenario tested, reducing infiltration by up to $40 \%$. Parker [28] supported this finding, stating that, for the warm, humid climate of south Florida, careful placement of trees and shrubs in relation to prevailing winds reduces infiltration during summer, and found a reduction of $50 \%$ cooling energy requirements on warm summer days for insulated mobile home.

Huang et al. [19] used a modelling approach to investigate meso- and micro-climates and their relationship to building energy. Using a building prototype of a single story residence of wood-frame construction, the study found that a $25 \%$ increase in tree cover can save $40 \%$ on residential cooling energy for Sacramento, CA, compared to $25 \%$ in Phoenix, AZ and Lake Charles, LA. The cooling energy savings increased to $50 \%$ and $33 \%$, respectively, when optimizing for shading.

In a study of residential buildings in Chicago, McPherson et al. [29] estimated 7.7\% $10.8 \%$ air-conditioning savings for one tree on the West wall of 1 and 2-storey brick buildings. In Sacramento, California, a study of two residential buildings estimated seasonal cooling energy savings of $29 \%$ solely through the use of sixteen shade trees [22]. More recently, an empirical study analysing electricity billing data in Sacramento by Donovan and Butry [30] found that trees on the South and West side of residential buildings reduced summertime energy consumption by $5.2 \%$ while trees on the North side increased consumption by $1.5 \%$. While the study does not explicitly state the percentage of the buildings being shaded, it does perform regression modelling to correlate electricity consumption with the ground area covered by trees within set distances from the buildings. 
By developing an empirical model based on residential data from Auburn, Alabama, Pandit and Laband [31] found 14\% savings in summer cooling energy for 50\% dense shade, but also a $6 \%$ increase in winter heating energy with $20 \%$ winter shading. In comparison, a modelling study by Nikoofard et al. [32] on four Canadian cities investigated the concept of neighbouring shading structures, including buildings and trees of various sizes, distances, and orientations from a modelled two-storey residence. It found that the largest impact for tree shading was in the Vancouver model, which reduced cooling energy by up to $36 \%$ (west side of building with tree size $=12 \mathrm{~m} \mathrm{H}$ x $8 \mathrm{~m} \mathrm{~W}$ of building) while increasing heating energy by only $1.2 \%$.

In Tokyo, Japan, Ca et al. [33] examined the influence of a nearby park during August and September by measuring air temperature, relative humidity, wind, foliage temperature and several surface temperatures. Through modelling of a four-storey building (20 m wide), the study estimated a $15 \%$ reduction in cooling energy requirements at noon with approximately $1.5{ }^{\circ} \mathrm{C}$ air temperature reduction. In a similar study, Chen \& Wong [34] studied the effects of a park on air temperature and cooling energy requirements in Singapore. The study found that the cooling effect of the park extended into the areas surrounding the park with a maximum temperature difference of $1.3{ }^{\circ} \mathrm{C}$ between the park and surroundings, with savings of up to $10 \%$ on cooling energy for an 8 -storey office building. The study considered energy savings due to air temperature cooling, but not the effects of shading, changes to relative humidity, or wind speed changes.

Using a numerical model, Kikegawa et al. [35] classified urban canopies (denoted as residential and office) in Tokyo, Japan according to SVF and investigated the effects of several different UHI countermeasures, including albedo increases, urban greening (ground, walls, or roof), reducing waste heat discharge, and conservation of cooling energy. In the residential canopies, the study estimated $0.7{ }^{\circ} \mathrm{C}$ reduction in air temperature and $20 \%$ 
reduction in building energy due to green walls, while the office canopies were shown to have the greatest reductions $\left(0.5^{\circ} \mathrm{C}\right.$ air temperature and $5 \%$ energy savings $)$ for the scenario that eliminated waste heat discharge from air conditioning.

In perhaps the most comprehensive study of this type, Akbari and Konopacki [36] developed summary tables of energy savings based on simulations employing a selection of UHI reduction strategies, including solar-reflective roofs, shade trees, and ambient cooling. The analysis looked at buildings that were profiled according to usage (residences, offices, and retail stores), age (Pre-1980 (old) or 1980+ (new)), and fuel (natural gas or electricity). Simulations estimated cooling and heating energy use and peak power demand using the DOE-2.1E model and weather data for about 240 locations in the United States. Energy use and savings per $1000 \mathrm{ft}^{2}$ of roof area were integrated to provide results tables sorted by heating and cooling degree-days. Savings were greatest for residential buildings, ranging from $12 \%$ to $25 \%$, and for office buildings, the electricity savings ranged from $5 \%$ to $18 \%$, depending on the age and climatic location (as characterised by HDD) of the building. Shading was estimated by placing a building element (block) next to the building with the estimated height and volume of a tree and assigning a transmittance ( 0.1 for summer, 0.9 for winter).

Raji et al. [37] developed a recent thorough literature review that discusses the energy impacts of several types of greening systems applied directly to buildings, including green roofs, walls, and balconies, sky gardens, and indoor sky gardens. Their review with regard to energy consumption concludes with wide variations over summer heating and cooling seasons. They found more effective and efficient energy reductions in all systems during the summer, but conflicting results for winter, depending on study conditions, such as climate location, orientation of the greening system and building age. 
This section has identified and discussed a range of studies on the impacts of vegetation on building energy. However, no single study addresses all aspects of vegetation modifications in urban environments and the studies demonstrate a wide range of energy reductions, from $5 \%$ up to $50 \%$, depending on building type, area of shading, estimated air temperature reductions, and climatic location.

While the current northern UK climate may currently have a relatively low demand for cooling energy, it is anticipated that cooling demand will rise significantly under projected climate change scenarios and will challenge designers to develop passive and lowenergy cooling in order to reduce the need for mechanical cooling [17]. Indeed, Akbari et al. [10] found that, for every $1{ }^{\circ} \mathrm{C}$ rise in daily maximum temperature (above a threshold of 15 $20{ }^{\circ} \mathrm{C}$ ), peak urban electric demand in six American cities (Los Angeles, CA; Washington, DC; Phoenix, AZ; Tucson, AZ; and Colorado Springs, CO) rises by $2-4 \%$. The estimation for the northern UK based on this is that the peak urban electricity demand may rise by 6$10 \%$ for a projected temperature rise of $3{ }^{\circ} \mathrm{C}$.

This research employed an interdisciplinary approach, first modelling fine-scale microclimate changes due to different types of greenspace and then using the results in combination with the measured UHII results to develop customised weather files for modelling building energy consumption. In addition to estimated weather changes, tree shading elements were added to each building, and finally, a green roof. The research presented contributes to knowledge of vegetation impacts on urban commercial buildings in a temperate maritime climate and is unique in its approach of using field measurements to inform the modelling parameters, as well as the use of physically representative tree models and the Suncast module of IES-VE to estimate shading, rather than cubical building blocks to represent shading elements. 


\section{Methods}

In determining the potential methods for this research, it is first important to consider that a large number of variables influence the microclimate interactions between buildings and greenspace. In an empirical study, each type of greenspace selected for measurement would be in a different location with different surroundings and the greenspace itself may be influenced by other factors, such as its location in the UHI, the building geometry, and surface characteristics surrounding it, thus making it difficult to determine whether the greenspace is influencing the built environment or vice versa.

Additionally, in this research it would be problematic to compare energy usage data for different buildings because the building mix in Greater Manchester is diverse in terms of age, size, construction materials, HVAC (heating, ventilation, and air conditioning) characteristics and occupancy rates. For residential buildings, the energy usage behaviour of individuals is very likely to cause significant variation even without consideration of other variables. Due to these limitations in empirical data, modelling was determined to be an important tool for assessing changes in building energy consumption due to different types and arrangements of greenspace.

Modelling in this research took place in two stages: microclimate modelling to assess differences in microclimate resulting from different greenspace types and arrangements; and building energy modelling to assess impacts to building energy. Temperature, humidity and wind speed outputs from the microclimate model were used to alter weather file inputs for the building energy modelling.

In addition to modelling as the primary investigative tool, this paper utilises extensive work on analysing the UHII in Manchester and Greater Manchester, a city and urban area in the northwest of England, UK. For this part of the research, air temperature data were collected using iButton temperature sensors that were placed on in radiation shields [38] on 
lampposts within selected study areas. The iButton sensors selected were the Maxim DS1922L temperature logging devices. Sensors were calibrated against a certified sensor (following procedures described by Cheung [2]) and set to take readings every half hour, at a resolution of $0.0625{ }^{\circ} \mathrm{C}$. iButton data were collected approximately once per quarter for a period of one year. The air temperature data served two purposes: 1) calibrating and validating the microclimate element of the modelling; and 2) determining the seasonal daytime and nighttime averages of the Manchester UHII [2].

\subsection{Urban Microclimate Modelling}

The modelling process first required a suitable energy balance model for urban areas. Many such models have been developed for fine-scale investigation of urban canyons and neighbourhoods [39,40]. While several models were considered - Canyon Air Temperature (CAT) [41], the Soil Model for Submesoscales, Urbanized Version (SM2U) [42] and Simple Urban Neighbourhood Boundary Energy Exchange Model (SUNBEEM) [43] - they are either slab or single-layer and did not include canopy details. Although multi-layer, the model SUNBEEM did not allow for differences in vegetation.

One model which met the objectives of the microclimate modelling is the model ENVI-met $[44,45]$. It is specifically designed for modelling surface-plant-air interactions in the urban environment. Full reasoning for this selection, the detailed settings used in this research (see Appendix A), and its benefits and limitations are discussed in Skelhorn et al. [46].

\subsection{Building Energy Modelling}

In the UK, AECOM oversees a Building Energy Calculation Software Approval Scheme on behalf of Communities and Local Government (CLG) [47]. Software is classified as domestic or non-domestic, with the latter further classified according to one of three types: 
- Operational Rating Calculation, which produces a display consumption certificate base on annual utility consumption data;

- Front-end interface for the simplified building energy modelling engine (FI-SBEM), which primarily provides a user-friendly interface for the CLG SBEM engine and produces an Energy Performance Certificate; and

- Dynamic Simulation Modelling (DSM), which can model the thermal dynamic response of buildings and demonstrate compliance with Part L of the Building Regulations [48].

Twelve programs are on the approved list for FI-SBEM, while only two, TAS and Virtual Environment by IES, are on the approved list for DSM.

One of the DSM programs, Virtual Environment (VE), was assessed as a suitable option for this research. IES-VE software has the advantages of being user-friendly as well as low cost to students and academic researchers. Hourly weather data required for simulations are available for Manchester from CIBSE and custom weather files can be created for testing the effects of changing weather patterns.

Modelling in IES-VE is achieved using the Model-It Module to size, place, and orient 3-D blocks to design the building's structure. The blocks can be modified in thickness and volume to provide realistic building elements, while surface coverings, construction elements, thermal profiles, HVAC and lighting schemes can also be adjusted to investigate a multitude of building designs. Importantly, for this research, the SunCast module is included for determining the effects of shading due to elements on or around the building.

The ApacheSim module controls the thermal dynamic simulation, including the modelling of conductive, convective, and radiative heat exchanges and integrating these with internal gains, air exchanges, and plant processes. Full descriptions of equations and solution methods are found in the ApacheSim Calculation Methods document [49]. Additionally, the methods have been tested and verified by CIBSE, as documented in TM33 [50]. 


\subsection{Modelling Processes}

As a guide to selection of study areas, a detailed look at both ENVI-met and IES-VE identified data inputs and parameters required for creating modelling scenarios. ENVI-met consists primarily of two input files. The first file is a configuration file, which allows input of file locations and initialisation parameters, such as locations of input and output folders, start time, interval for saving data, initial wind speeds and other initial values. The second file is an area file, which allows input of a detailed layout of the site, including buildings with heights, locations and heights of trees and other vegetation, and soil types.

Areas to be modelled are input on a rectangular grid which can range from small areas less than $20 \times 20$ cells up to a maximum of $250 \times 250$ cells, with each cell having a resolution of $0.5 \mathrm{~m}$ up to $10 \mathrm{~m}$. Example models loaded with ENVI-met range from $30 \mathrm{x} 30$ up to $150 \mathrm{x}$ 150 cells, with typical cell resolutions of 3-5 m. Larger model areas and/or higher resolution models require significantly longer running times, so it was important to select a model size and resolution that was manageable within the timeframe of this research project.

Model timing is determined by the user, with a typical model running from early morning for a period of 24 hours and saving data once per hour. As typical for numerical models, total running time can last several days, considering that one simulation hour can require 4-6 hours or upwards of model running time, depending on the size of the model area and level of detail in the model.

On completion of the microclimate modelling, the second modelling stage was to estimate energy changes due to additional greenspace by using IES-VE 2012. For this stage, three buildings were designed with suitable constructions for walls, floors, windows, and roof. According to the N-DEEM (non-domestic energy and emissions) model $[51,52]$ developed by the Building Research Establishment (BRE), energy end usage (cooling, 
heating, lighting, hot water) is estimated according to building characteristics, including: activity group (office, retail, hotels), construction type, and size.

Although residential (or domestic) and commercial buildings were both considered initially, it was found that the two are very different in terms of structural, ventilation, and HVAC characteristics. Residential buildings can be difficult to model due to widely differing occupancy rates and timings, and unpredictable usage of heating, lighting, and electronics. Additionally, a report on climate change impacts for London notes that residential buildings are less of a problem in terms of UHI and climate change because less heat is gained from equipment while individuals also have more control over windows, doors, and other comfort measures [53]. Recognizing that the usage will vary by the building's primary activity, it was decided to focus the research and modelling on commercial buildings.

Data outputs from ENVI-met and analysis of the iButton air temperature data were used to inform the changes to weather inputs in IES-VE. Tree elements were added to models to test the effects of shading.

\subsection{Description of Building Models}

The simulation focuses on office buildings, as discussed previously. A large number of variables can affect the simulation of the building energy usage, including building characteristics such as age, building construction, ratio of natural gas to electricity consumption, occupancy rates, and HVAC characteristics [54]. CIBSE and the BRE have identified four typical types of office buildings in the UK [55],

- Naturally ventilated, cellular (individual offices or divided meeting rooms);

- Naturally ventilated, open plan;

- Air conditioned, standard; and

- Air conditioned, prestige. 
As the research is interested in the energy trade-offs that might occur in airconditioned buildings, modelling was based on the latter two types. A total of three buildings were examined:

- Two versions of Type 3, one shallow-plan three-storey, and one shallow-plan tenstorey; and

- Type 4, one deep-plan three-storey.

The buildings were sketched using the ModelIT module in IES-VE. To test the interaction of glazing ratios and shading, each building was first modelled with $20 \%$ glazing, then with $50 \%$ glazing. Table 1 provides the building details while Figures 2, 3, and 4 show the three buildings as sketched in IES-VE. All buildings were modelled as a General Office and it is assumed that all buildings have been modernized in terms of windows, doors, light fittings and insulation.

Table 1 - Building Types and Descriptions

\begin{tabular}{|l|l|l|l|c|}
\hline $\begin{array}{c}\text { Building Type } \\
\text { Designation }\end{array}$ & \multicolumn{1}{|c|}{$\begin{array}{c}\text { Plan } \\
\text { Type }\end{array}$} & $\begin{array}{c}\text { Glazing } \\
\text { Ratios }\end{array}$ & Floor Area and Layout & Height (Floors) \\
\hline A & Shallow & $20 \%, 50 \%$ & $\begin{array}{l}972 \mathrm{~m}^{2}-9(6 \mathrm{~m} \times 6 \mathrm{~m}) \text { rooms per } \\
\text { floor }\end{array}$ & 3 \\
\hline B & Shallow & $20 \%, 50 \%$ & $3240 \mathrm{~m}^{2-}$ same layout as building A & 10 \\
\hline C & Deep & $20 \%, 50 \%$ & $\begin{array}{l}5418 \mathrm{~m}^{2}-84(3 \mathrm{~m} \times 3 \mathrm{~m}) \text { rooms }, 4 \\
\text { open plan areas }(10 \mathrm{~m} \times 15 \mathrm{~m}), 18\end{array}$ \\
larger offices $(5 \mathrm{~m} \times 5 \mathrm{~m})$
\end{tabular}




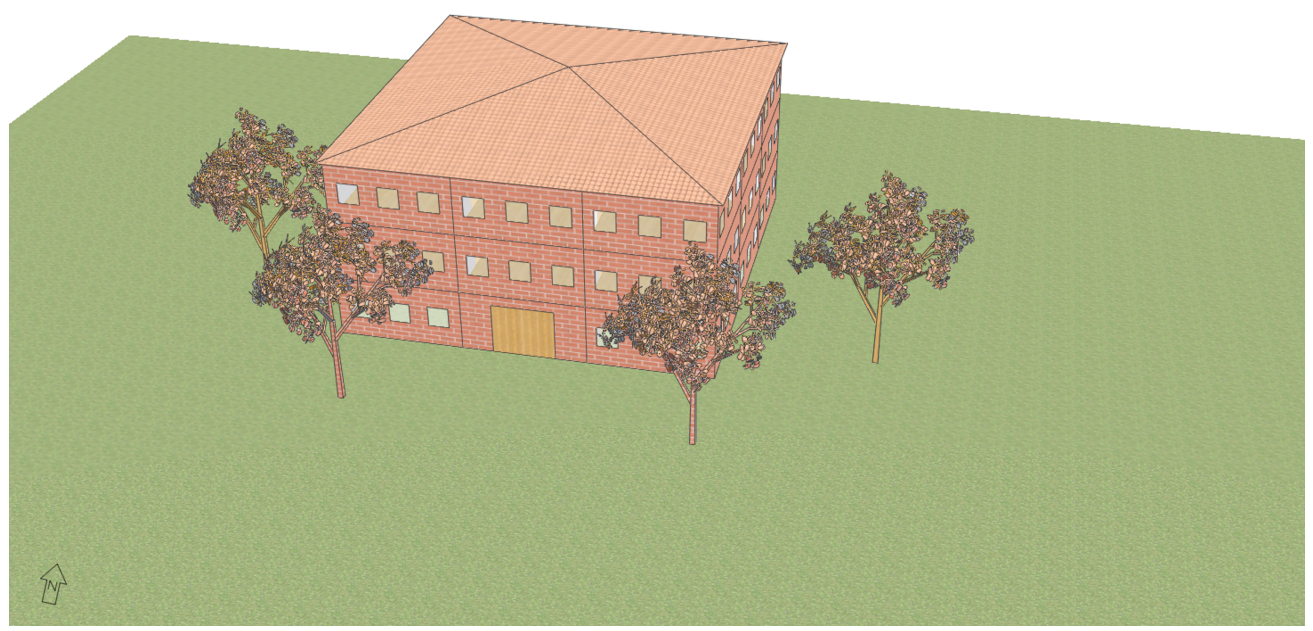

Figure 2 - Building A - Three-Storey Shallow Plan

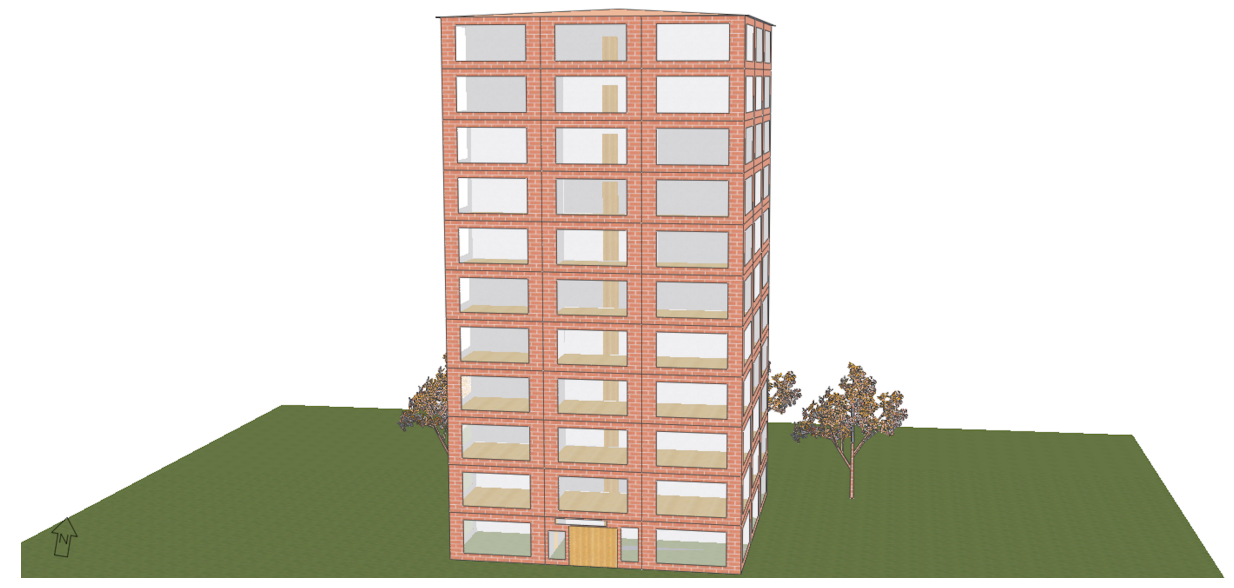

Figure 3 - Building B - Ten-Storey Shallow Plan 


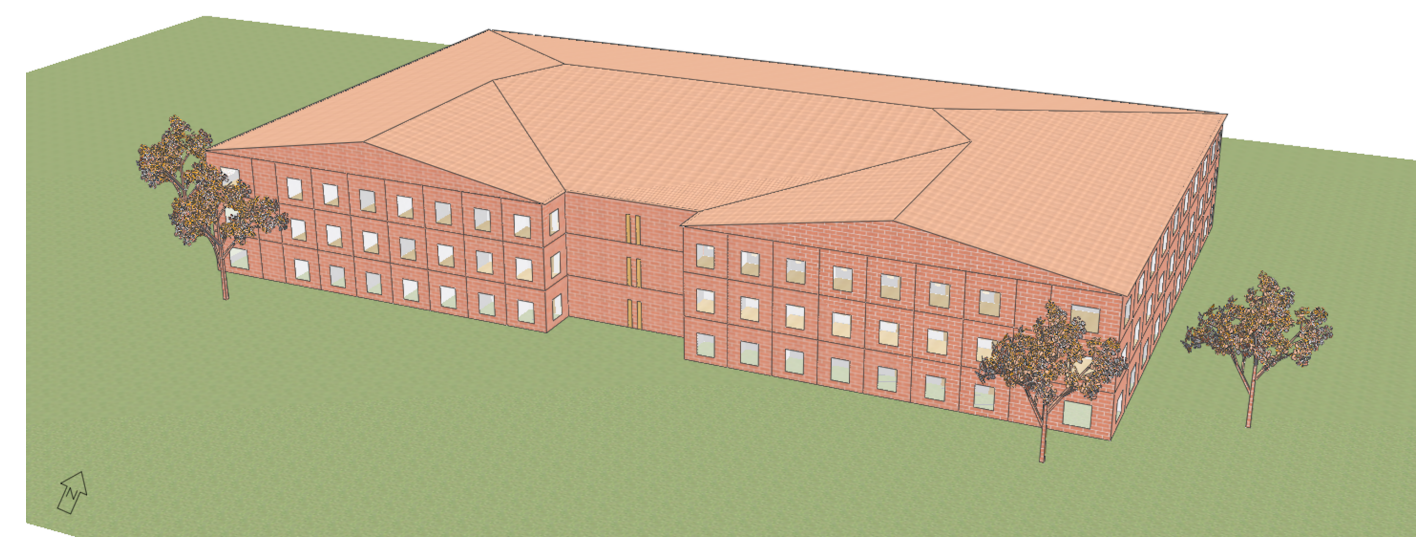

Figure 4 - Building C - Three-Storey Deep Plan

Building constructions applied were the 2002 Building Regulations for England and Wales [56], as follows:

- Roof - flat roof, $\mathrm{U}-\mathrm{value}=0.25 \mathrm{~W} /\left(\mathrm{m}^{2} \mathrm{~K}\right)$;

- Ceiling - carpeted $100 \mathrm{~mm}$ reinforced concrete ceiling;

- Exernal wall - standard wall construction, 2002 regulations;

- Internal partition - $13 \mathrm{~mm}$ plaster, $105 \mathrm{~mm}$ brick, $13 \mathrm{~mm}$ plaster;

- Ground floor - Standard floor construction; and

- Door - wooden.

The building was cooled by a constant volume package system and sized based on peak cooling loads, post room-load calculations. The thermal template is designated as Plant Type 1 in IES-VE, with other thermal template parameters set as follows:

- Timing - Office 8:00 am - 6:00 pm;

- Cooling setpoint $-23.0^{\circ} \mathrm{C}$, with $\mathrm{AC}$ setback of $28^{\circ} \mathrm{C}$ from 6:00 pm - 7:00 am; 
- Heating equipment - Boiler with gas;

- Heating setpoint $-19.0^{\circ} \mathrm{C}$;

- $\mathrm{RH}-70 \%$ maximum;

- $\mathrm{ACH}-0.250$ Infiltration, representing a value for newer air tightness regulations;

- Outside air supply flow rate $-0.80 \mathrm{l} / \mathrm{s} / \mathrm{m}^{2}$; and

- Internal Gains:

- Fluorescent lighting, $12 \mathrm{~W} / \mathrm{m}^{2}$;

○ People - Maximum Sensible Heat Gain, 90 W/person; Maximum Latent Heat Gain, $60 \mathrm{~W} /$ person; Occupancy $14 \mathrm{~m}^{2} /$ person;

- Equipment, $12 \mathrm{~W} / \mathrm{m}^{2}$.

\subsection{Summer Energy Scenarios}

Each building was first modelled with the July TRY weather data for Manchester Airport (no shading elements) as a base estimate of cooling energy usage for summer. This base case was then compared with two models that incorporated tree shading; the first model added four trees on the North side of the building, while the second model added four trees on the South side of the building. A third scenario tested the effect of a green roof. Then, additional models tested UHI increases or reductions, and wind speed reductions. Trees of 10 $\mathrm{m}$ height were selected as the shading element given that mature trees were found to have the most effect in the microclimate modelling discussed in Section 2.1. The model names and descriptions were:

Base - Building in suburban conditions, without shading, modelled with July TRY weather data; 
Shade - North Four trees added as Topographic Shade, two on the North and one on each of the Northwest and Northeast corners of the building, shading approximately $20 \%$ of the building; and South - Four trees added as Topographic Shade, two on the South side and one on each Southwest and Southeast corners of the building, again shading approximately $20 \%$ of the building;

Urb_UHI - To simulate each building's energy increase due to the UHI (i.e., a building placed in urban conditions), a new weather file (UHI+6) was created using the EPW creator Excel spreadsheet from IES-VE. In this weather file the hourly daytime temperatures from the July TRY weather file were adjusted by $+1.5{ }^{\circ} \mathrm{C}(5: 00 \mathrm{am}-10: 00 \mathrm{pm})$, and nighttime by $+3{ }^{\circ} \mathrm{C}(10: 00 \mathrm{pm}-5: 00 \mathrm{am})$. These values are based on a Manchester $\mathrm{PhD}[2]$ showing average summer daytime and nighttime UHII. Additionally, in the TRY dataset, nearly two full days in July (16th-18th) are clear, calm and warm days, which are conditions for an intense UHI, so temperatures were increased strongly, $+3{ }^{\circ} \mathrm{C}$ for daytime and $+6{ }^{\circ} \mathrm{C}$ for nighttime;

Urb_UHI_green - To test the effect of greening (shading plus reduced UHII peak hours), a new weather file (UHI+6_green) was created based on the TRY_UHI+6 file. The UHII on the peak days (16th-18 $8^{\text {th }}$ July) was reduced by $1{ }^{\circ} \mathrm{C}$, in effect taking off the peak of the UHI. In this weather file, the UHII for the peak days is $+2{ }^{\circ} \mathrm{C}$ for daytime $(5: 00 \mathrm{am}-$ 10:00 pm) and $+5{ }^{\circ} \mathrm{C}$ for nighttime $(10: 00 \mathrm{pm}-5: 00 \mathrm{am})$. This reduction in UHII due to greening is based on the negative summer correlation between UHII and area of tree canopy from an analysis that formed part of a Manchester thesis [57]. The regression equation indicates a potential reduction of 10 cooling degree hours for each $5 \%$ increase in greenspace. The weather file changes here are scaled up, allowing for a total of 40 cooling degree hours due to the $20 \%$ shading around the shallow-plan three-storey building. 
Urb_UHI_green_wind - To test the effect of a reduced wind speed, a new weather file (UHI+6_green_wind) was created based on the TRY_UHI+6_green file. In addition to the changes in the two previous scenarios, this file also reduced the hourly wind speeds for July by $1 \mathrm{~m} / \mathrm{s}$. The reduction is based on the wind speed reductions for the mature trees scenario of the urban microclimate modelling discussed in the previous section [46].

Green Roof - The green roof was modelled as an extensive green roof with sedum and low grasses as the vegetation layer. The model construction followed as closely as possible (given available material settings in IES-VE) the diagram in Figure 5, with an overall U-value of $0.22 \mathrm{~W} /\left(\mathrm{m}^{2} \mathrm{~K}\right)$.

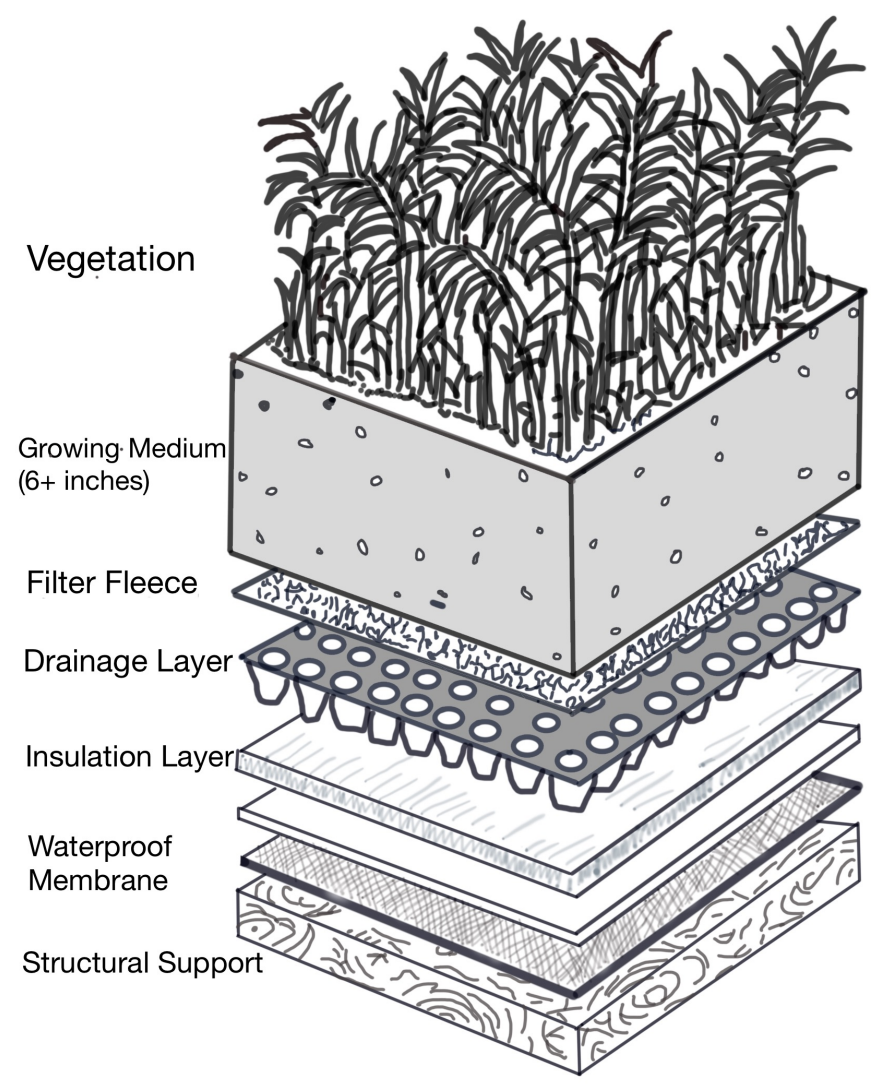

Figure 5 - Example Green Roof Construction [58] 


\section{Results}

\subsection{Building Energy Modelling for July}

Table 2 provides a summary of results for the models tested in IES-VE 2012. First, the increase in glazing ratio from $20 \%$ to $50 \%$ increases chiller energy by a factor of 1.6 for the shallow plan buildings (A and B) and a factor of 1.3 for the deep plan building (C). The effect of the UHI alone, as demonstrated by changing the location of the buildings from suburban (base case) to an urban location with an average summertime UHI (Urb_UHI) increases the chiller energy requirements from $9.4 \%-12.2 \%$, depending on the building design and glazing ratio.

Shading with four trees on the North side of a building reduces chiller energy by $0.3 \%$ - $1.0 \%$, while shading with four trees on the South side of a building leads to reductions of $0.4 \%-1.7 \%$. The maximum reduction of $1.7 \%$ was achieved for Building A with $50 \%$ glazing (shallow-plan three-storey) while the least reductions were in Building B with 20\% glazing.

Analysis of the scenario that combined four trees shading the south side of the building with the reduction of UHII peak hours (Urb_UHI_shade) shows a maximum of 1.7\% reduction in chiller energy for Building A (50\% glazing). Total reductions for this same building with the combined effects of four trees on the North and four trees on the South are estimated at $2.7 \%$.

Continuing with this scenario (Urb_UHI_shade), the percentage savings is less than half for a deep plan building (C) (only $0.7 \%$ ) primarily because the same four trees in this scenario will not be shading an equivalent surface area (only $10 \%$ of the building's surface in this model). However, if the model had achieved the $20 \%$ shading of the shallow-plan building, this would lead to $1.4 \%$ savings, slightly less than the reduction achieved in the 
shallow plan building (A). This is reasonable due to the larger internal building volume for a deep-plan building that would be unaffected by shading measures.

For the green roof scenario, the summer results for all buildings show a very marginal increase in chiller energy consumption $(0.3 \%)$. The buildings modelled in this study have well insulated roofs in the base model, and much of the literature indicates that an insulated roof will perform equally well in comparison to a green roof [37] without insulation. Therefore, it is anticipated that the particular construction of the green roof plays an important role in its functioning for building energy.

Wind speed reductions are sometimes cited as a thermal advantage due to lower infiltration rates. However, this is usually understood as a problem that would apply to poorly insulated buildings [37,59]. The results in the scenario for urban greening with wind speed reductions (Urb_UHI_green_wind) show that any advantage due to the greening is almost entirely counteracted if the wind speed is also reduced. For a well-insulated building, the lower wind speeds can be detrimental because of the reduction in heat transport away from the building envelope in summer. 


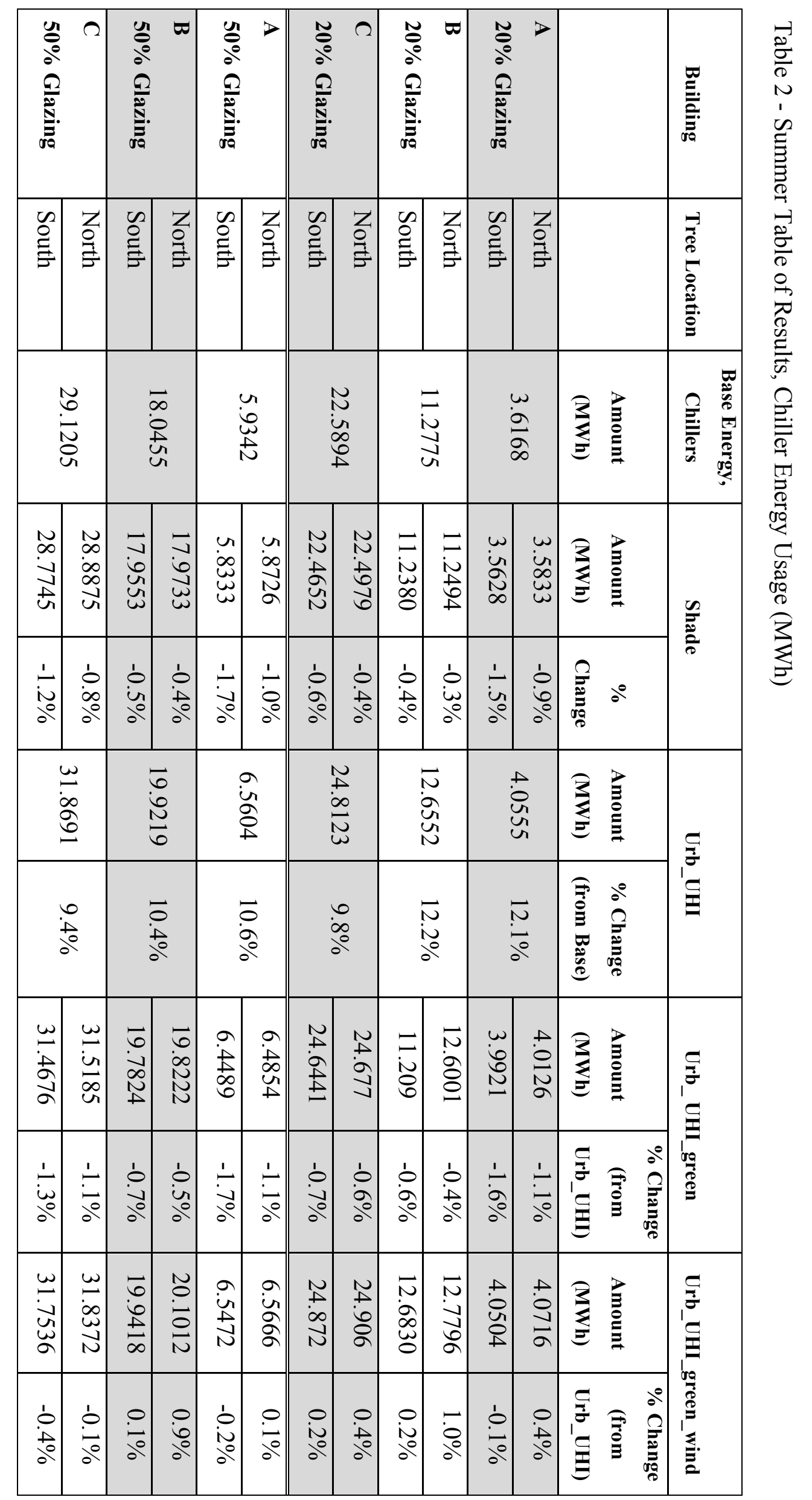




\subsection{Building Energy Modelling for Peak UHII}

While the effect of tree shading and UHII reduction appear to be small when considered over the entire month, as presented in the previous table, the results can also be examined more closely for the effects during the peak UHII period. The following table (Table 3) shows the peak UHII conditions for the set of buildings with $20 \%$ glazing (as seen from the monthly results, the values for the buildings with $50 \%$ glazing are similar). The results for this period show that shading by four trees on the South side of building A can reduce the cooling energy by $2.7 \%$ in a building located in the UHI. In this case, a reduction in wind speed is not considered because the peak UHII occurs on days of low wind. The 10storey shallow plan building (B) and deep plan building (C) are similar to each other in reductions for this 3-day period of peak UHII conditions.

Table 3 - Summer Table Results for Peak UHI $\left(16^{\text {th }}-18^{\text {th }}\right.$ July $)$

\begin{tabular}{|c|c|c|c|c|}
\hline Building & $\begin{array}{c}\text { Tree } \\
\text { Location }\end{array}$ & Urb_UHI & \multicolumn{2}{|c|}{ Urb_UHI green } \\
\hline $20 \%$ Glazing & & Amount (kWh) & Amount (kWh) & $\begin{array}{c}\% \text { Change } \\
\text { (from Urb_UHI) }\end{array}$ \\
\hline \multirow[t]{2}{*}{ A } & North & \multirow{2}{*}{572.0} & 560.2 & $-2.1 \%$ \\
\hline & South & & 556.6 & $-2.7 \%$ \\
\hline \multirow[t]{2}{*}{ B } & North & \multirow{2}{*}{1738.4} & 1711.7 & $-1.5 \%$ \\
\hline & South & & 1705.4 & $-1.9 \%$ \\
\hline \multirow[t]{2}{*}{$\mathrm{C}$} & North & \multirow{2}{*}{3209.6} & 3161.4 & $-1.5 \%$ \\
\hline & South & & 3156.4 & $-1.7 \%$ \\
\hline
\end{tabular}

One final point is that savings may be greater in air-conditioned buildings that are occupied during the nighttime, when UHII is greatest. The buildings in this study are modelled as office buildings, so the air conditioning is turned off at night during unoccupied 
hours, masking the potential savings for buildings that are occupied at this time, such as hospitals, retail, or food service uses.

\section{Discussion}

As discussed in the introduction, numerous studies demonstrate that vegetation can play an important role in determining the microclimate of urban locations, and consequently, influence the energy performance of buildings. The research presented here specifically focuses on the impact of the shading, air temperature, and wind effects of trees on urban commercial buildings in Manchester, UK.

Results here can be compared to several other studies that have included vegetation impacts on building energy consumption. For instance, Akbari and Konopacki's study of UHI reduction strategies [36] grouped results by climate location according to Heating Degree Days (HDD) and Cooling Degree Days (CDD). Office buildings were modelled and found to save $7.2 \%$ through shade tree reduction measures $(\mathrm{CDD}<200$, corresponding to a Manchester climate which experienced a yearly CDD of 107, on average for 2012 2015)[60]. Trees were modelled as rectangular blocks (15 ft x15 ft x10 ft per tree, with a transmittance of 0.9) placed on South and West walls at $2 \mathrm{ft}$ clearance, with a total of 8 trees for the office building. This arrangement led to approximately $42 \%$ shading of the building's total exterior wall area. The estimated energy reduction is nearly four times higher than the result presented here of $1.6 \%-1.7 \%$ for trees on the South side of a building. However, when considering that the shaded area in that study is slightly more than double that presented here and also considers trees planted on the West side where reductions may be higher, it is likely that the results are closely comparable. 
A few other studies have found somewhat higher energy savings. The modelling study of $\mathrm{Ca}$ et al. [33] estimated 15\% reduction in cooling energy at noon (four-storey building not specified as commercial or residential) in Tokyo, Japan. Also in Tokyo, Kikegawa et al. [35] used numerical modelling to investigate various UHI counter-measures and found that reducing waste heat from air conditioning in office canopies was the most effective measure (5\% reduction on average, across differing sky-view factors), when compared to greening strategies, including green roofs, green walls, and ground surface greening. Chen \& Wong [34] found savings of up to $10 \%$ on cooling energy for an 8 -storey office building due to air temperature cooling from a nearby park. The study considered energy savings due to air temperature cooling, but not the effects of shading, changes to relative humidity, or wind speed changes.

For commercial buildings, the larger building volume to envelope ratio is the determining factor in building energy usage with regard to vegetation impacts. Whereas residential studies have shown significant reductions in energy demand due to vegetation - up to $47 \%$ [5] - this study concludes that the larger building envelope and building volumes in commercial buildings reduces the potential impacts of vegetation. Strategic placement (on the south or west side, for instance) of vegetation is needed in order to achieve noticeable benefits and attention is needed to the percentage of building area shaded in order to reduce solar gain through the building envelope.

A number of studies can be found for comparisons to the green roof scenario. A study by Ascione et al. [61] found that a green roof in a heating dominant country (Netherlands, Norway, UK) can reduce cooling demand by $6-7 \%$ for a one-story building. Other studies have found wide variation, depending on the green roof construction, climate, building height and building insulation [32]. For instance, Santamouris [62] found 6-33\% 
monthly cooling load savings for a two-storey nursery in the Mediterranean climate of Athens. The results here are consistent with a study by Jaffal et al. [63], which found that insulation is a dominant factor in the effectiveness of a green roof. When considering a onestorey residential building, the authors found that $10 \mathrm{~cm}$ of insulation dominated any cooling energy savings of a green roof- i.e., if a building has a well insulated roof, the green roof has little impact to additional energy savings. Similarly, Niachou et al. [64] found $45 \%$ cooling and heating energy savings for a green roof on a non-insulated building in a Mediterranean climate, but savings of $0 \%$ cooling energy (and 2\% heating energy) for the same building with insulation. The roof construction in the base model for this research has a maximum UValue of $0.25 \mathrm{~W} / \mathrm{m}^{2} \mathrm{~K}$, which appears to be performing slightly better than the green roof scenario. The simulation in IES-VE is limited to conductive heat exchange through the roof as well as the available construction materials in IES-VE. It does not account for air temperature cooling due to evapotranspiration that can take place within a height of $1-2 \mathrm{~m}$ above the green roof [65].

While it is well established that a higher UHII is strongly correlated with low wind speeds, the study considers the effect of reduced wind speeds due to additional vegetation. The results in this study indicate that consideration must be given to planting schemes that will provide shade and/or temperature reductions, but also not impede wind flow at the building envelope during summer. Based on the microclimate results showing wind speed reductions due to vegetation, careful siting is needed for trees that have the potential to be large at maturity. Such trees should be planted close enough to buildings to provide shade, but at a distance that will not obstruct wind flow. Therefore, the mature crown size should be taken into account in the planning stage and a gap between building and tree crown should be allowed to permit wind flow across the building envelope during summer. 
In terms of targeting neighbourhoods for redevelopment or retrofitting, an initial assessment should target areas with buildings having a high percentage of glazing. In the building energy results, large increases in chiller energy usage (up to 64\%) occur for the single change from $20 \%$ glazing to $50 \%$ glazing. Therefore, in terms of controlling energy usage and carbon emissions, greening programs should begin by targeting buildings that are highly glazed, providing shade on the south and west sides of a building in Northern latitudes. Such targeted measures could have the largest impact, allowing time and resources to be devoted to the areas that would most benefit from thermal enhancement.

\section{Conclusions}

The research first utilised the urban microclimate model ENVI-met to model an urban study area, estimating average changes in air temperature, relative humidity, and wind. These microclimate results and an analysis of the Manchester UHII based on iButton temperature sensors were then used to inform the building energy modelling performed in IES-VE. The research focused on the effect of vegetation on the energy performance of commercial buildings by assessing three factors - shading with mature trees, reduction in total number of hours at peak UHII conditions, and changes in wind speed.

The effect of the summer UHI alone increased the air conditioning load between $9 \%$ and $12 \%$. For the scenario of adding $5 \%$ mature trees to the urban case study, the combination of microclimate modelling and iButton data analysis estimated a maximum hourly air temperature reduction of nearly $1.0{ }^{\circ} \mathrm{C}$ under peak UHI conditions and wind speed reductions up to $1.0 \mathrm{~m} / \mathrm{s}$. These results were used to change the weather files in the building energy modelling, which estimated a reduction of $2.8 \%$ in July chiller energy due to the combination of reduced UHII peak hours and eight additional trees (four on the north side 
and four on the south side) shading a three-storey shallow plan building. These energy savings increased to $4.8 \%$ under a three-day period of peak UHII conditions.

While residential studies often include large numbers of trees and shading (and/or high shading coefficients, $>0.8$ or greater), blocking most solar irradiance from building walls, this might be unrealistic for large commercial buildings, especially in densely built urban areas. Therefore, the results here fill a gap in literature on simulations for urban commercial buildings in a temperate maritime climate, and point to much lower, but not insignificant savings, for such scenarios.

\section{Appendix A}

Table A-1 - ENVI-met settings, Comparison of Initial to Final Values for ManchesterWythenshawe Base Model [46]

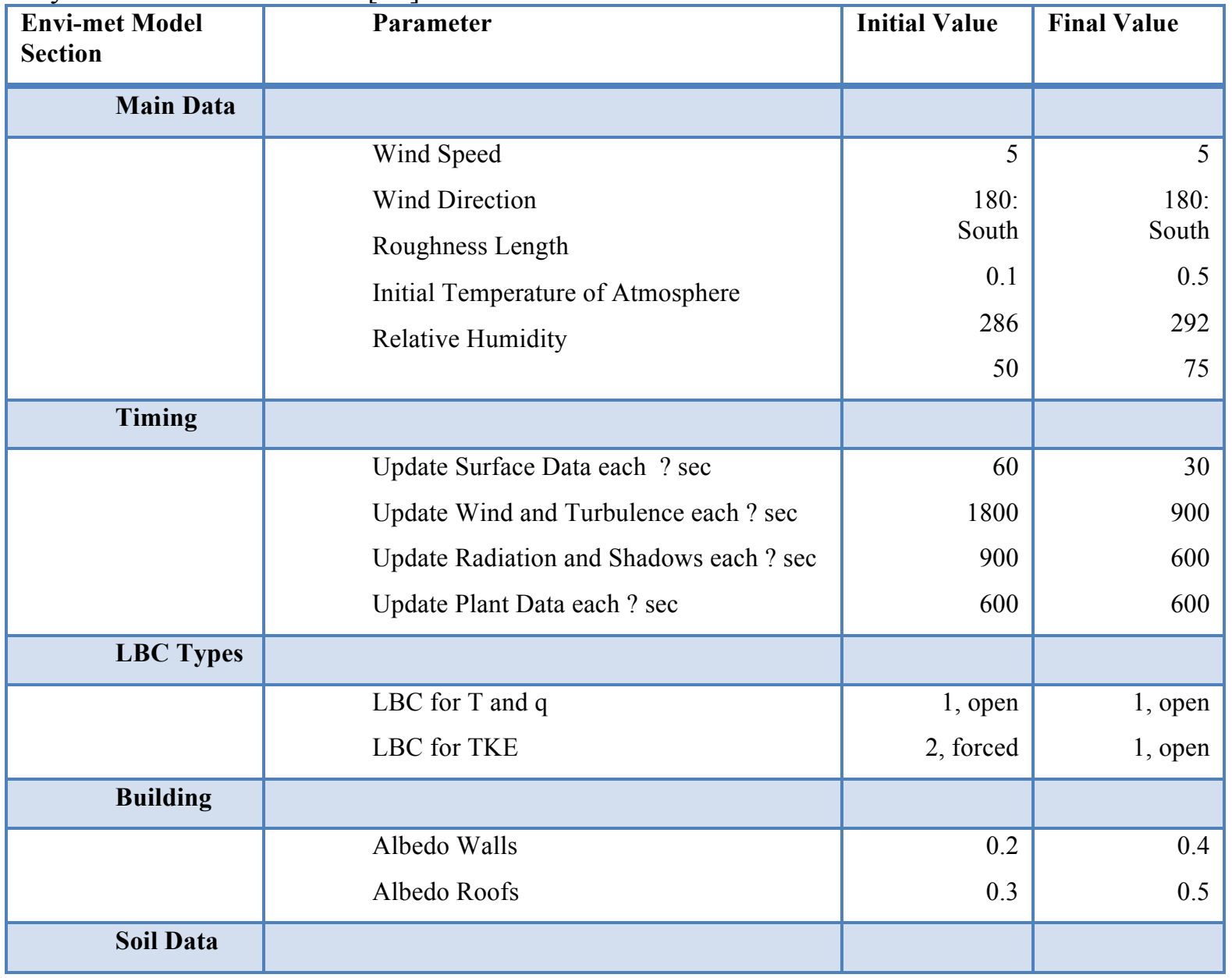




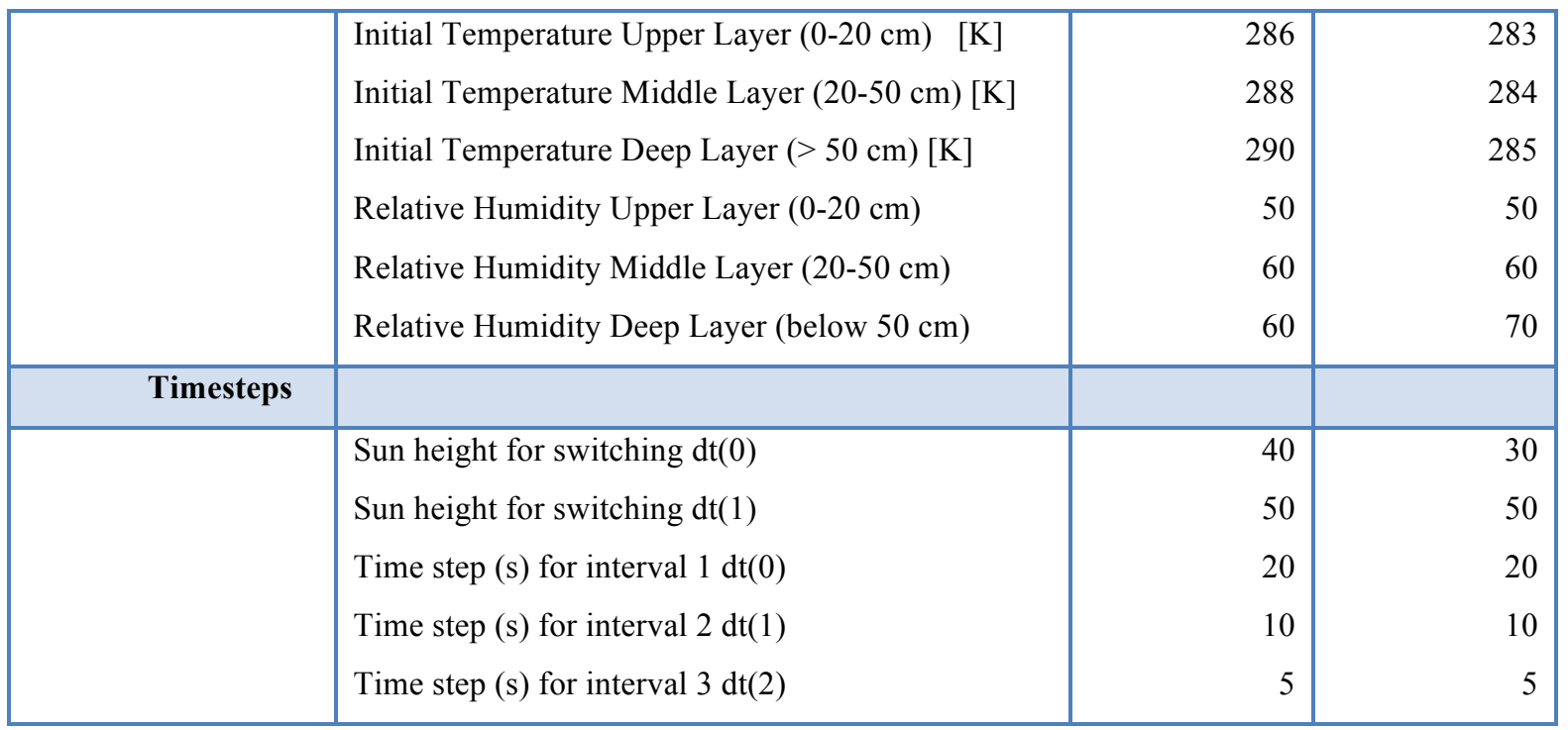

\section{Acknowledgements}

The authors would like to thank the reviewers for their constructive comments, which have made a significant contribution to improving the coherence of this research.

This research formed part of the programme of the UK Energy Research Centre and was supported by the UK Research Councils under Natural Environment Research Council award NE/C513169/1.

\section{References}

[1] UK Met Office, UK Climate Projections: Summer Mean Temperature, (2009). $\mathrm{http}$ ://ukclimateprojections.metoffice.gov.uk/23673?emission=medium (accessed December 13, 2015).

[2] H.K.W. Cheung, An urban heat island study for building and urban design, University of Manchester, 2011.

[3] G. Levermore, J. Parkinson, The Manchester urban heat island and adjustments for CIBSE calculations, CIBSE ASHRAE Tech. Symp. (2014).

[4] S.E. Gill, J.F. Handley, A.R. Ennos, S. Pauleit, Adapting cities for climate change: The role of the green infrastructure, Built Environ. 33 (2007) 115-133.

[5] D.E. Bowler, L. Buyung-Ali, T.M. Knight, A.S. Pullin, Urban greening to cool towns and cities: A systematic review of the empirical evidence, Landsc. Urban Plan. 97 (2010) 147-155. doi:10.1016/j.landurbplan.2010.05.006. 
[6] R.A. Spronken-Smith, T.R. Oke, Scale modelling of nocturnal cooling in urban parks, Boundary-Layer Meteorol. 93 (1999) 287-312.

[7] X. Cao, A. Onishi, J. Chen, H. Imura, Quantifying the cool island intensity of urban parks using ASTER and IKONOS data, Landsc. Urban Plan. 96 (2010) 224-231. doi:10.1016/j.landurbplan.2010.03.008.

[8] M. Noro, R. Lazzarin, Urban heat island in Padua, Italy: Simulation analysis and mitigation strategies, Urban Clim. 14 (2015) 187-196.

doi:10.1016/j.uclim.2015.04.004.

[9] D. Armson, P. Stringer, A.R. Ennos, The effect of tree shade and grass on surface and globe temperatures in an urban area, Urban For. Urban Green. 11 (2012) 245-255. doi:10.1016/j.ufug.2012.05.002.

[10] H. Akbari, S. Davis, S. Dorsano, J. Huang, S. Winnett (Eds.), Cooling Our Communities: A Guidebook On Tree Planting and Light-Colored Surfacing, U.S. Environmental Protection Agency, Office of Policy Analysis, Climate Change Division, Washington, D.C., 1992.

[11] H. Upmanis, I. Eliasson, S. Lindqvist, The influence of green areas on nocturnal temperatures in a high latitude city (Göteborg, Sweden), Int. J. Climatol. 18 (1998) 681-700. doi:10.1002/(SICI)1097-0088(199805)18:6<681::AID-JOC289>3.0.CO;2-L.

[12] C.R. Chang, M.-H. Li, S.-D. Chang, A preliminary study on the local cool-island intensity of Taipei city parks, Landsc. Urban Plan. 80 (2007) 386-395.

[13] M. Davies, P. Steadman, T. Oreszczyn, Strategies for the modification of the urban climate and the consequent impact on building energy use, Energy Policy. 36 (2008) $4548-4551$.

[14] M. Santamouris, N. Papanikolaou, I. Livada, I. Koronakis, C. Georgakis, A. Argiriou, et al., On the impact of urban climate on the energy consumption of buildings, Sol. Energy. 70 (2001) 201-216.

[15] R. Watkins, J. Palmer, M. Kolokotroni, Increased temperature and intensification of the urban heat island: Implications for human comfort and urban design, Built Environ. 33 (2007) 85-96.

[16] D.B. Belzer, M.J. Scott, R.D. Sands, Climate change impacts on U.S. commercial building energy consumption: an analysis using sample survey data, Energy Sources, Part A Recover. Util. Environ. Eff. 18 (1996) 177-201.

[17] M.J. Holmes, J.N. Hacker, Climate change, thermal comfort and energy: Meeting the design challenges of the 21st century, Energy Build. 39 (2007) 802-814.

[18] M. Kolokotroni, X. Ren, M. Davies, A. Mavrogianni, London's urban heat island: Impact on current and future energy consumption in office buildings, Energy Build. 47 (n.d.) 302-311. doi:http://dx.doi.org/10.1016/j.enbuild.2011.12.019.

[19] Y.J. Huang, H. Akbari, H. Taha, A.H. Rosenfeld, The Potential of Vegetation in Reducing Summer Cooling Loads in Residential Buildings, J. Clim. Appl. Meteorol. 26 (1987) 1103-1116. doi:10.1175/1520-0450(1987)026<1103:TPOVIR>2.0.CO;2.

[20] E.G. McPherson, L.P. Herrington, G.M. Heisler, Impacts of vegetation on residential 
heating and cooling, Energy Build. 12 (1988) 41-51. doi:10.1016/03787788(88)90054-0.

[21] E.G. McPherson, J.R. Simpson, M. Livingston, Effects of three landscape treatments on residential energy and water use in Tucson, Arizona, Energy Build. 13 (1989) 127138. doi:10.1016/0378-7788(89)90004-2.

[22] H. Akbari, D.M. Kurn, S.E. Bretz, J.W. Hanford, Peak power and cooling energy savings of shade trees, Energy Build. 25 (1997) 139-148. doi:http://dx.doi.org/10.1016/S0378-7788(96)01003-1.

[23] D.N. Laband, J.P. Sophocleus, An experimental analysis of the impact of tree shade on electricity consumption, Arboric. Urban For. 35 (2009) 197-202.

[24] G. Papadakis, P. Tsamis, S. Kyritsis, An experimental investigation of the effect of shading with plants for solar control of buildings, Energy Build. 33 (2001) 831-836. doi:10.1016/S0378-7788(01)00066-4.

[25] J.R. Simpson, E.G. McPherson, Potential of tree shade for reducing residential energy use in California, J. Arboric. 22 (1996) 10-18.

[26] H.J. de Blij, P.O. Muller, Physical Geography of the Global Environment, Wiley, Canada, 1993.

[27] G.E. Mattingly, E.F. Peters, Wind and trees: Air infiltration effects on energy in housing, J. Wind Eng. Ind. Aerodyn. 2 (1977) 1-19. doi:http://dx.doi.org/10.1016/0167-6105(77)90002-2.

[28] J.H. Parker, Landscaping to reduce the energy used In cooling buildings, J. For. 81 (1983) 82-84 + 105 .

[29] E.G. Mcpherson, Energy-Saving Potential of Trees in Chicago, in: USDA For. Serv. Gen. Tech. Rep. NE-186, Davis, CA, 1994.

[30] G.H. Donovan, D.T. Butry, The value of shade: Estimating the effect of urban trees on summertime electricity use, Energy Build. 41 (2009) 662-668. doi:10.1016/j.enbuild.2009.01.002.

[31] R. Pandit, D.N. Laband, Energy savings from tree shade, Ecol. Econ. 69 (2010) 1324 1329. doi:10.1016/j.ecolecon.2010.01.009.

[32] S. Nikoofard, V.I. Ugursal, I. Beausoleil-Morrison, Effect of external shading on household energy requirement for heating and cooling in Canada, Energy Build. 43 (2011) 1627-1635. doi:10.1016/j.enbuild.2011.03.003.

[33] V.T. Ca, T. Asaeda, E.M. Abu, Reductions in air conditioning energy caused by a nearby park, Energy Build. 29 (1998) 83-92. doi:http://dx.doi.org/10.1016/S03787788(98)00032-2.

[34] Y. Chen, N.H. Wong, Thermal benefits of city parks, Energy Build. 38 (2006) 105120.

[35] Y. Kikegawa, Y. Genchi, H. Kondo, K. Hanaki, Impacts of city-block-scale countermeasures against urban heat-island phenomena upon a building's energyconsumption for air-conditioning, Appl. Energy. 83 (2006) 649-668. 
[36] H. Akbari, S. Konopacki, Calculating energy-saving potentials of heat-island reduction strategies, Energy Policy. 33 (2005) 721-756. doi:10.1016/j.enpol.2003.10.001.

[37] B. Raji, M.J. Tenpierik, A. van den Dobbelsteen, The impact of greening systems on building energy performance: A literature review, Renew. Sustain. Energy Rev. 45 (2015) 610-623. doi:10.1016/j.rser.2015.02.011.

[38] H.K.W. Cheung, G.J. Levermore, R. Watkins, A low cost, easily fabricated radiation shield for temperature measurements to monitor dry bulb air temperature for the urban heat island effect, Build. Serv. Eng. Res. Technol. 31 (2010) 371-380.

[39] F. Ali-Toudert, H. Mayer, Numerical study on the effects of aspect ratio and orientation of an urban street canyon on outdoor thermal comfort in hot and dry climate, Build. Environ. 41 (2006) 94-108. doi:10.1016/j.buildenv.2005.01.013.

[40] A. Baklanov, C.S.B. Grimmond, A. Mahura, M. Athanassiadou, Meteorological and Air Quality Models for Urban Areas, Springer-Verlag, Berlin Heidelberg, 2009.

[41] E. Erell, T. Williamson, Simulating air temperature in an urban street canyon in all weather conditions using measured data at a reference meteorological station, Int. J. Climatol. 26 (2006) 1671-1694. doi:10.1002/joc.1328.

[42] S. Dupont, P.G. Mestayer, E. Guilloteau, E. Berthier, H. Andrieu, Parameterization of the urban water budget with the submesoscale soil model, J. Appl. Meteorol. Climatol. 45 (2006) 624-648. doi:10.1175/JAM2363.1.

[43] A.J. Arnfield, A simple model of urban canyon energy budget and Its validation, Phys. Geogr. 21 (2000) 305-326.

[44] M. Bruse, H. Fleer, Simulating surface-plant-air interactions inside urban environments with a three dimensional numerical model, Environ. Model. Softw. 13 (1998) 373-384.

[45] M. Bruse, ENVI-met 3.0: Updated Model Overview, (2004). http://www.envi-met.com (accessed September 20, 2014).

[46] C. Skelhorn, S. Lindley, G. Levermore, The impact of vegetation types on air and surface temperatures in a temperate city: A fine scale assessment in Manchester, UK, Landsc. Urban Plan. 121 (2014) 129-140. doi:10.1016/j.landurbplan.2013.09.012.

[47] M.C.N. Lim, UK building energy software approval scheme, in: Elev. Int. IBPSA Conf., Glasgow, Scotland, 2009: pp. 553-568.

[48] HMSO, L2A conservation of fuel and power in new buildings other than dwellings, The NBS, London, 2010.

[49] IES-VE, ApacheSim calculation methods, IES, 2011.

[50] CIBSE, Tests for software accreditation and verification CIBSE TM33: 2006, The Chartered Institution of Building Services Engineers, London, 2006.

[51] C.H. Pout, N-DEEM: the national nondomestic buildings energy and emissions model, Environ. Plan. B Plan. Des. 27 (2000) 721-732.

[52] P. Steadman, H.R. Bruhns, B. Gakovic, Inferences about built form, construction, and fabric in the nondomestic building stock of England and Wales, Environ. Plan. B Plan. 
Des. 27 (2000) 733-758.

[53] S. Clarke, J. Kersey, E. Trevorrow, R. Wilby, S. Shackley, J. Turnpenny, et al., London's Warming - The Impacts of Climate Change on London, London Climate Change Partnership, London, 2002.

[54] S. Heiple, D.J. Sailor, Using building energy simulation and geospatial modeling techniques to determine high resolution building sector energy consumption profiles, Energy Build. 40 (2008) 1426-1436.

[55] CIBSE, Energy consumption guide 19: Energy use in offices, (2000).

[56] HMSO, Building and Buildings, England and Wales, The Stationery Office Limited, London, 2002.

[57] C. Skelhorn, A fine scale assessment of urban greenspace impacts on microclimate and building energy in Manchester, University of Manchester, 2013.

[58] J. Stoddard, C. Bissonnette, Roof Farm Photos, (2012). http://higher-groundfarm.com/roof-farm-photos/\#jp-carousel-22 (accessed June 20, 2013).

[59] H. Akbari, Shade trees reduce building energy use and $\mathrm{CO} 2$ emissions from power plants, Environ. Pollut. 116 (2002) S119-S126. doi:10.1016/S0269-7491(01)00264-0.

[60] Degreedays.net, Celsius-based cooling degree days for base temperatures at and around 18.0C, StationID: EGCC - Manchester Airport, Degreedays.net. (2015). http://www.degreedays.net/\#generate (accessed June 1, 2015).

[61] F. Ascione, N. Bianco, F. de' Rossi, G. Turni, G.P. Vanoli, Green roofs in European climates. Are effective solutions for the energy savings in air-conditioning?, Appl. Energy. 104 (2013) 845-859. doi:10.1016/j.apenergy.2012.11.068.

[62] M. Santamouris, C. Pavlou, P. Doukas, G. Mihalakakou, A. Synnefa, A. Hatzibiros, et al., Investigating and analysing the energy and environmental performance of an experimental green roof system installed in a nursery school building in Athens, Greece, Energy. 32 (2007) 1781-1788. doi:10.1016/j.energy.2006.11.011.

[63] I. Jaffal, S.-E. Ouldboukhitine, R. Belarbi, A comprehensive study of the impact of green roofs on building energy performance, Renew. Energy. 43 (2012) 157-164. doi:10.1016/j.renene.2011.12.004.

[64] A. Niachou, K. Papakonstantinou, M. Santamouris, A. Tsangrassoulis, G. Mihalakakou, Analysis of the green roof thermal properties and investigation of its energy performance, Energy Build. 33 (2001) 719-729. doi:10.1016/S03787788(01)00062-7.

[65] A.F. Speak, J.J. Rothwell, S.J. Lindley, C.L. Smith, Reduction of the urban cooling effects of an intensive green roof due to vegetation damage, Urban Clim. 3 (2013) 4055. doi:10.1016/j.uclim.2013.01.001. 